\title{
Erratum: Is It Attachment Style or Socio-Demography: Singlehood in a Representative Sample
}

\section{OPEN ACCESS}

Approved by:

Psychology Editorial Office,

Frontiers, Switzerland

*Correspondence:

Frontiers Production Office production.office@frontiersin.org

Specialty section:

This article was submitted to Personality and Social Psychology,

a section of the journal

Frontiers in Psychology

Received: 03 December 2015 Accepted: 03 December 2015

Published: 14 December 2015

Citation:

Frontiers Production Office (2015) Erratum: Is It Attachment Style or Socio-Demography: Singlehood in a

Representative Sample.

Front. Psychol. 6:1946.

doi: 10.3389/fpsyg.2015.01946

\section{Frontiers Production Office *}

Frontiers Production Office, Frontiers, Switzerland

Keywords: adult attachment scale, attachment style, partnership status, representative sample, single person

\section{An erratum on}

Is It Attachment Style or Socio-Demography: Singlehood in a Representative Sample by Petrowski, K., Schurig, S., Schmutzer, G., Brähler, E., and Stöbel-Richter, Y. (2015). Front. Psychol. 6:1738. doi: 10.3389/fpsyg.2015.01738

Reason for Erratum:

Due to a misunderstanding the Acknowledgment Section was missing from the published article. The publisher apologizes for this error and the original article has been updated.

This error does not change the scientific conclusions of the article in any way.

Copyright () 2015 Frontiers Production Office. This is an open-access article distributed under the terms of the Creative Commons Attribution License (CC BY). The use, distribution or reproduction in other forums is permitted, provided the original author(s) or licensor are credited and that the original publication in this journal is cited, in accordance with accepted academic practice. No use, distribution or reproduction is permitted which does not comply with these terms. 